\title{
Mengembangkan Kognitif Anak Melalui Penggunaan Media Bahan Alam Pada Kelompok B
}

\author{
Mulianah Khaironi \\ TK Negeri 1 Taliwang \\ Email: guru.anah@gmail.com
}

\begin{abstract}
ABSTRAK
Penelitian ini bertujuan untuk meningkatkan kemampuan kognitif anak kelompok B melalui penggunaan media bahan alam. Sampel dalam penelitian ini adalah 8 orang peserta didik yang berusia 5-6 tahun. Dalam penelitian ini, data diperoleh melalui pengamatan menggunakan lembar observasi. Analisis data menggunakan analisis data kuantitatif secara deskriptif. Hasil penelitian pada siklus 1 pertemuan 1 rata-rata perkembangan kognitif anak mencapai 60\%, dan pada pertemuan ke-2 mencapai 66\%. Pada siklus 2, yaitu pada pertemuan ke-1 memperoleh persentase rata-rata $80 \%$ dan rata-rata $87 \%$ pada pertemuan ke-2. Selain mengembangkan kognitif, penggunaan bahan alam dapat meningkatkan interaksi peserta didik dengan alam, sehingga peserta didik dapat mengeksplor alam untuk mengembangkan kognitifnya. Hal tersebut menunjukkan bahwa terdapat pengembangan kognitif anak kelompok B melalui penggunaan media bahan alam.
\end{abstract}

Kata Kunci: Kognitif, Media Bahan Alam, Kelompok B

\section{ABSTRACT}

This research which aims to improve the cognitive abilities of group B children through the use of natural media. The sample in this study were 8 students aged 5-6 years. In this study, data were obtained through observations using observation sheets. Data analysis uses descriptive quantitative. The results showed the average cognitive development of children reached at the cycle 1 meeting 1 is $60 \%$, and at meeting 2 reached is $66 \%$. At the cycle 2, i.e. at the 1st meeting, the percentage was an average of $80 \%$ and an average of $87 \%$ at the 2 nd meeting. In addition to developing cognitive, the use of natural materials can increase students' interaction with nature, so students can explore nature to develop their cognitive. This shows that there is cognitive development of group B children through the use of natural media.

Keywords: Cognitive, Natural Materials Media, Group B3

\section{PENDAHULUAN}

Anak usia taman kanak-kanak adalah individu yang berada dalam perkembangan eksplosif. Pada usia ini perkembangan sangat rentan, artinya perkembangan anak akan mencapai optimal sesuai indikator perkembangan pada usia tersebut jika mendapatkan stimulasi yang sesuai dengan tahapan usianya, melalui penggunaan media, dan dilaksanakan secara terus-menerus. Dalam rangka peletakan dasar ke arah pengembangan sikap, pengetahuan, keterampilan dan kemampuan kognitifnya, anak perlu diberikan stimulasi, 
bimbingan dari orang terdekat terutama orang tua/pendidiknya (Khadijah, 2016; Purnamasari \& Nurhayati, 2019).

Manusia sebagai makhluk hidup mesti mengalami perkembangan di setiap waktunya, tak terkecuali pada anak usia dasar (7-13 tahun). Salah satu aspek penting dari perkembangan adalah aspek kogntif. Perkembangan kognitif merupakan suatu perkembangan yang sangat komprehensif yaitu berkaitan dengan kemampuan berpikir, seperti kemampuan mengingat, bernalar, beride, berimajinasi dan kreativitas (Aprilianti, 2017; Arimbi et al., 2018; Elfiadi, 2016; Rosita, Fadillah, 2018) Karakteristik anak usia taman kanak-kanak sebagai individu yang aktif membutuhkan sarana untuk menyalurkan energi yang dimiliki, baik energi fisik, kreativitas, maupun pengetahuan. Kognitif adalah suatu proses berpikir, yaitu kemampuan individu untuk menghubungkan, menilai dan mempertimbangkan suatu kejadian atau peristiwa (Indarwarti, 2017; Kasumayanti \& Elina, 2018)

Perkembangan kognitif adalah proses dimana individu dapat meningkatkan kemampuan dalam menggunakan pengetahuannya. Perkembangan kognitif anak perlu distimulasi dan diberi rangsangan agar dapat meningkat Perkembangan kognitif adalah suatu proses berfikir yaitu kemampuan untuk menghubungkan, menilai dan mempertimbangkan suatu kejadian atau peristiwa. Potensi kognitif ditentukan pada saat konsepsi (pembuahan) namun terwujud atau tidaknya tergantung dari lingkungan dan kesempatan yang diberikan (adawiyah agustina et al., 2015; Rosita, Fadillah, 2018; Yuliastri, Nur Adiyah \& ramdhani, 2018)).

Studi tentang perkembangan kognitif, terutama pada anak usia sekolah, telah menjadi salah satu fokus utama penelitian perkembangan selama 25 tahun terakhir. Ada banyak sekali literatur penelitian, dengan ribuan studi yang menyelidiki perubahan kognitif dari sejumlah perspektif tertentu. Berikut adalah lingkup perkembangan kognitif anak berdasarkan Peraturan Menteri Pendidikan Nasional Republik Indonesia Nomor 58 Tahun 2009 Tentang Standar Pendidikan Anak Usia Dini: usia $0-<2$ tahun, yaitu: mengenal apa yang diinginkan, menunjukkan reaksi terhadap rangsangan, mengenali pengetahuan umum, mengenal konsep ukuran dan bilangan; usia 2-<4 tahun, yaitu: mengenal pengetahuan umum, mengenal konsep ukuran, bentuk, dan pola; usia $4-\leq 6$ tahun, yaitu: pengetahuan umum dan sains, konsep bentuk, warna, ukuran dan pola, Konsep bilangan, lambang bilangan dan huruf (Khaironi, 2018; Rahman Taopik, 2017).

Kemampuan Kognitif Anak Usia 5-6 Tahun antara lain: (1) Sudah dapat memahami jumlah dan ukuran; (2) Tertarik dengan huruf dan angka. Ada yang sudah mampu menulis dan menyalin serta menghitung; (3) Telah mengenal sebagian besar warna; (4) Mulai mengerti tentang waktu, kapan harus pergi ke sekolah dan pulang dari sekolah, nama-nama hari dalam satu minggu; (5) Mengenal bidang dan bergerak sesuai dengan bidang yang dimilikinya (teritorinya); (6) Pada akhir usia 6 tahun, anak sudah mulai mampu membaca, menulis dan berhitung (Nur Hayati, Nur Cholimah, 2017) Dalam Kurikulum Pendidikan Anak Usia Dini, kompetensi dasar 3.6/4.6 KI-3/KI-4, yaitu: mengenali diri, keluarga, teman, pendidik dan/atau pengasuh, lingkungan sekitar, teknologi, seni, dan budaya di rumah, tempat bermain dan satuan PAUD dengan cara: mengamati dengan indra (melihat, mendengar, 
menghidung, merasa, meraba); menanya; mengumpulkan informasi; mengolah informasi/mengasosiasikan, dan mengomunikasikan.

\section{METODE PENELITIAN}

Penelitian ini adalah penelitian tindakan kelas. Peneliti meneliti tentang Mengembangkan Kognitif Anak Melalui Penggunaan Media Bahan Alam pada Kelompok B3 TK Negeri 1 Taliwang. Subyek dalam penelitian ini adalah 8 orang peserta didik kelompok B3 usia 5-6 tahun. Indikator keberhasilan dalam penelitian ini adalah kemampuan kognitif anak mencapai $75 \%$ melalui penggunaan media bahan alam. Pengumpulan data menggunakan pedoman observasi. Analisis data yang digunakan adalah analisis data kuantitatif secara deskriptif. (Nuraeni, 2016) menjelaskan bahwa analisis statistik deskriptif adalah statistik yang digunakan untuk menganalisis data dengan cara mendeskripsikan atau menggambarkan data yang telah terkumpul sebagaimana adanya tanpa bermaksud membuat kesimpulan yang berlaku untuk umum atau generalisasi.

\section{HASIL DAN PEMBAHASAN}

Penelitian ini terdiri dari 2 siklus. Setiap siklus terdiri dari 2 pertemuan. Dalam pelaksanaan kegiatan penelitian, peneliti menggunakan media bahan alam untuk mengembangkan kognitif anak kelompok B3 di TK Negeri 1 Taliwang Kabupaten Sumbawa Barat. Bahan alam tersebut berupa berbagai benda yang diperoleh dari lingkungan sekitar sekolah, baik dari bahan hayati (biotik), maupun non hayati (abiotik). Adapun indikator kognitif yang diamati dalam PTK ini adalah kemampuan mengenal bentuk, ukuran, warna, dan bilangan.

Tabel 0.1 Hasil Pengamatan Mengembangkan Kognitif Anak Melalui Penggunaan Media Bahan Alam pada Kelompok B3 TK Negeri 1 Taliwang

\begin{tabular}{|c|c|c|c|c|c|c|c|c|c|c|}
\hline \multirow{3}{*}{$\begin{array}{l}\text { NAMA } \\
\text { ANAK }\end{array}$} & \multicolumn{10}{|c|}{ SIKLUS 1} \\
\hline & \multicolumn{4}{|c|}{ PERT. 1} & \multirow{2}{*}{$\begin{array}{c}\text { SKOR } \\
(\%)\end{array}$} & \multicolumn{4}{|c|}{ PERT.2 } & \multirow{2}{*}{$\begin{array}{c}\text { SKOR } \\
(\%)\end{array}$} \\
\hline & BENTUK & UKURAN & WARNA & BILANGAN & & BENTUK & UKURAN & WARNA & BILANGAN & \\
\hline $\mathrm{RE}$ & 2 & 3 & 3 & 3 & 69 & 2 & 3 & 3 & 3 & 69 \\
\hline SHA & 2 & 3 & 3 & 3 & 69 & 2 & 3 & 3 & 3 & 69 \\
\hline NO & 2 & 2 & 2 & 2 & 50 & 2 & 3 & 3 & 2 & 63 \\
\hline ZAH & 2 & 3 & 3 & 2 & 63 & 2 & 3 & 3 & 3 & 69 \\
\hline DA & 2 & 3 & 3 & 3 & 69 & 2 & 3 & 3 & 3 & 69 \\
\hline ALF & 2 & 2 & 2 & 2 & 50 & 2 & 3 & 3 & 2 & 63 \\
\hline ATY & 2 & 2 & 2 & 2 & 50 & 2 & 3 & 3 & 2 & 63 \\
\hline NJW & 2 & 3 & 3 & 2 & 63 & 2 & 3 & 3 & 2 & 63 \\
\hline & & RATA-RA & & & 60 & & RAT $A$ & RATA & & 66 \\
\hline
\end{tabular}




\begin{tabular}{ccccccccccc} 
NAMA & \multicolumn{3}{c}{ PERT. 1 } & \multicolumn{3}{c}{ SKOR } & \multicolumn{2}{c}{ PERT. 2 } & SKOR \\
ANAK & BENTUK & UKURAN & WARNA & BILANGAN & $(\%)$ & BENTUK & UKURAN & WARNA & BILANGAN & $\begin{array}{c}(\%) \\
\text { RE }\end{array}$ \\
\hline & 3 & 4 & 4 & 4 & 94 & 3 & 4 & 4 & 4 & 94 \\
SHA & 3 & 4 & 4 & 4 & 94 & 3 & 4 & 4 & 4 & 94 \\
NO & 3 & 3 & 3 & 3 & 75 & 3 & 3 & 3 & 3 & 75 \\
ZAH & 3 & 3 & 3 & 3 & 75 & 3 & 4 & 4 & 4 & 94 \\
DA & 3 & 3 & 3 & 3 & 75 & 3 & 4 & 4 & 4 & 94 \\
ALF & 3 & 3 & 3 & 3 & 75 & 3 & 4 & 3 & 3 & 81 \\
ATY & 3 & 3 & 3 & 3 & 75 & 3 & 3 & 3 & 3 & 75 \\
NJW & 3 & 3 & 3 & 3 & 75 & 3 & 4 & 4 & 3 & 88 \\
& & RATA-RATA & & & 80 & & RATA-RATA & 87
\end{tabular}

Berdasarkan hasil penelitian yang diperoleh, diketahui bahwa setiap peserta didik mengalami peningkatan persentase kemampuan kognitif mengenal bentuk, ukuran, warna, dan bilangan. Hal tersebut dijelaskan seperti berikut ini: pada siklus 1 pertemuan ke-1 dan ke2 persentase kemampuan kognitif Ananda Re mencapai 69\%, dan meningkat menjadi 94\% pada siklus 2. Hal tersebut menunjukkan bahwa pada akhir pertemuan (siklus) tindakan, setiap anak memperoleh persentase $\geq 75 \%$, sehingga penggunaan media bahan alam untuk menstimulasi kemampuan kognitif anak kelompok B3 di TK Negeri 1 Taliwang dapat dikatakan berhasil.

Adanya peningkatan kemampuan kognitif menggunakan media bahan alam juga diketahui pada penelitian. Hasil penelitian tersebut menyimpulkan bahwa penggunaan media bahan alam dalam kegiatan proses pembelajaran dapat membantu mengembangkan aspek perkembangan anak seperti motorik halus, kognitif dan kreativitas anak, karena dengan menggunakan media alam dapat memudahkan anak untuk menyerap pengetahuan dan membantu mengembangkan pola pikir anak. Hal tersebut juga didukung oleh (Oktari, 2017) media bahan alam dapat dimanfaatkan sebagai media dalam belajar. Pemanfaatan media bahan alam sebagai media pembelajaran oleh guru secara tepat akan membantu anak dalam menggembangkan berbagai aspek perkembangan anak baik aspek kognitif, sosial emosional, bahasa, motorik, moral dan nilai-nilai agama serta kecakapan hidup (life Skill).

Dalam Kurikulum Pendidikan Anak Usia Dini, kompetensi dasar yang terditi atas mengenali diri, keluarga, teman, pendidik dan/atau pengasuh, lingkungan sekitar, teknologi, seni, dan budaya di rumah, tempat bermain dan satuan PAUD dengan cara: mengamati dengan indra (melihat, mendengar, menghidung, merasa, meraba); menanya; mengumpulkan informasi; mengolah informasi/mengasosiasikan, dan mengomunikasikan melalui kegiatan bermain, menunjukkan bahwa kemampuan kognitif dapat dikembangkan melalui kegiatan mengenal/menyampaikan tentang apa dan bagaimana benda-benda di sekitarnya (nama, warna, bentuk, ukuran, pola, sifat, suara, tekstur, fungsi, dan ciri-ciri lainnya) benda-benda di sekitar yang dikenalnya (Nasution, 2016; Windarsih et al., 2017)

Alam merupakan salah satu sumber belajar yang menyediakan berbagai hal sebagai media pembelajaran. Manfaat penggunaan media bahan alam dalam pembelajaran adalah 
meningkatkan kemampuan akademik, perkembangan pribadi, dan kedekatan dengan lingkungan. Alam menawarkan pembelajaran untuk meningkatkan perhatian pembelajar, meningkatkan kedisiplinan, meningkatkan ketertarikan dan kenyamanan dalam pembelajaran. Dibandingkan dengan pembelajaran tradisional, pelaksanaan sekolah yang melibatkan alam sebagai media dapat meningkatkan prestasi akademik. Dalam uji coba terkontrol secara acak yang melibatkan berbagai siswa siswa, pembelajaran yang menggunakan kebun/taman sekolah, lebih banyak memperoleh pengatahuan daripada pembelajaran kelas tradisional (Arimbi et al., 2018; Pagestu, 2017).

\section{KESIMPULAN}

Media bahan alam dapat digunakan untuk mengembangkan kognitif anak, yaitu mengenalkan konsep bentuk, ukuran, warna, dan bilangan. Hasil penelitian menunjukkan terdapat peningkatan kemampuan kognitif melalui penggunaan media bahan alam pada kelompok B3 di TK Negeri 1 Taliwang mencapai rerata 87\%. Oleh karena itu, guru dapat memanfaatkan alam yang ada di lingkungan sekitar lembaga pendidikan anak usia dini sebagai salah satu alternatif untuk mengatasi keterbatasan media di lembaga masing-masing.

\section{DAFTAR PUSTAKA}

Adawiyah Agustina, R., Shofa Ilhami, B., \& Najamuddin. (2015). Pengembangan Model Permainan Tradisional Engklek Edukatif Dalam Mengembangkan Kemampuan Motorik Kasar Dan Kognitif Anak Usia 5-6 Tahun. 5-6.

Aprilianti, R. (2017). Meningkatkan Kemampuan Membilang Angka 1 Sampai 20 Melalui Permainan Bendera Pintar Pada Anak Usia 5-6 Tahun. Jurnal Golden Age Universitas Hamzanwadi, 02(4), 22-33.

Arimbi, Y. D., Saparahayuningsih, S., \& Ardina, M. (2018). Meningkatkan Perkembangan Kognitif Melalui Kegiatan Mind Mapping. Jurnal Ilmiah Potensia, 3(2), 64-71. Https://Ejournal.Unib.Ac.Id/Index.Php/Potensia/Article/View/2603/2689

Elfiadi. (2016). Bermain Dan Permainan Bagi Anak Usia Dini. Jurnal Itqan, Vii(1), 51-60.

Indarwarti, A. (2017). Mengembangkan Kecerdasan Kognitif Anak Melalui Beberapa Metode. 109-118.

Kasumayanti, E., \& Elina, Y. (2018). Perkembangan Kognitif Anak Usia 5-6 Tahun Di Tinjau Dari Tingkat Pendidikan Ibu Di Paud Kasih Ibu Kecamatan Rumbai. Paud Lectura: Jurnal Pendidikan Anak Usia Dini, 1(2), 186-197. Https://Doi.Org/10.31849/Paudlectura.V1i2.1179

Khadijah. (2016). Pengembangan Kognitif Anak Usia Dini. Https://Doi.Org/10.1016/S02628856(98)00132-2

Khaironi, M. (2018). Perkembangan Anak Usia Dini. Jurnal Golden Age Hamzanwadi University, 3(1), 1-12. 
Nasution, R. A. (2016). Pembelajaran Seni Musik Bagi Pengembangan Kognitif Anak Usia Dini. Jurnal Keguruan Uin Sumatera Utara, Iv, 11-21.

Nur Hayati, Nur Cholimah, M. C. (2017). Kata Kunci : Keterampilan Kognitif, Anak Usia Dini. Pendidikan Anak Is Licensed Under A Creative, 6(2), 181-189.

Nuraeni, A. (2016). Peran Orang Tua Dalam Pengembangan Literasi Dini Anak Kelompok B Di Gugus 7 Mangunan Dlingo Bantul. Jurnal Pendidikan Anak Usia Dini, 3, 245-256. Http://Journal.Student.Uny.Ac.Id/Ojs/Index.Php/Pgpaud/Article/Viewfile/1256/1131

Oktari, V. M. (2017). Penggunaan Media Bahan Alam Dalam Pembelajaran Di Taman Kanak-Kanak Kartika I-63 Padang. Paud Lectura: Jurnal Pendidikan Anak Usia Dini, Vol 1 No 1 (2017): Paud Lectura, 49-57. Https://Journal.Unilak.Ac.Id/Index.Php/PaudLectura/Article/View/503

Pagestu, R. (2017). Ratna Pangastuti. Fenomena Gadget Dan Perkembangan Sosial Bagi Anak Usia Dini.

Purnamasari, A., \& Nurhayati, N. (2019). Faktor-Faktor Yang Mempengaruhi Kemampuan Kognitif Anak Usia 5-6 Tahun Di Taman Kanak-Kanak. Kindergarten: Journal Of $\begin{array}{lllll}\text { Islamic Early } & \text { Childhood }\end{array}$ Https://Doi.Org/10.24014/Kjiece.V1i2.6657

Rahman Taopik, S. F. F. (2017). Peningkatan Kemampuan Anak Usia Dini Mengenal Lambang Bilangan Melalui Media Playdough. 1(Desember), 118-128.

Ramdani, Z., \& Ramdhani, S. (2020, May). Information And Communication Technology (Ict) Within The Scope Of Early Childhood Development. In Journal Of Physics: Conference Series (Vol. 1539, No. 1, P. 012071). Iop Publishing.

Rosita, Fadillah, D. Y. (2018). Pengembangan Potensi Kognitif Anak Melalui Bermain Kontruksi Dengan Lego Di Tk Kartika V-49 Pontianak.

Saroinsong, W. P., Anggraeni, N., \& Adhe, K. R. (2020). Boosting Kognitif Pada Anak; Diseminasi Survey Domino Konvensional Vs Domino Digital. Jurnal Golden Age, $4(01), 112-127$.

Windarsih, C. A., Jumiatin, D., Efrizal, E., Sumini, N., \& Utami, L. O. (2017). Implementasi Pendidikan Anak Usia Dini Inklusif Dikota Cimahi Jawa Barat. P2m Stkip Siliwangi, 4(2), 7. Https://Doi.Org/10.22460/P2m.V4i2p7-11.636

Yuliastri, N. A., \& Ramdhani, S. (2018). Pengembangan Pembelajaran Tematik Integratif Untuk Meningkatkan Nilai Karakter Anak Usia Dini. Jurnal Golden Age, 2(01), 44-58. 